\title{
Factors Determining Consumer Fraud Reporting in Kenya
}

\author{
Rodgers A. Musamali, ${ }^{1, *}$ \\ ${ }^{1}$ Private Sector Development Division, Kenya Institute for Public Policy Research and \\ Analysis (KIPPRA), Nairobi, Kenya \\ *Correspondence: Private Sector Development Division, Kenya Institute for Public Policy \\ Research and Analysis (KIPPRA), P. O. Box 56445, 00200, Nairobi, Kenya. Tel: \\ 254-721-727-117. E-mail: rmusamali@gmail.com
}

Received: July 9, 2014 Accepted: August 8, 2014 Published: August 28, 2014

doi:10.5296/rae.v6i3.5945 URL: http://dx.doi.org/10.5296/rae.v6i3.5945

\begin{abstract}
This study examines the factors determining consumer fraud reporting in Kenya. It presents cross sectional evidence from data collected by the United Nations Office on Drugs and Crime and KIPPRA in 2009/2010. Descriptive results show that the most prevalent consumer fraud in Kenya is the proliferation of counterfeit goods. Using logit model, the study finds that consumer fraud reporting is affected by the type of the fraud where proliferation of counterfeit goods is important but negatively associated to reporting. This connotes that the more people are victimized, the more they fail to report to the police or other relevant authorities. This finding puts the fight against counterfeits into perspective perhaps underpinning the important attention it needs to continue receiving from the government and other relevant institutions. More awareness by the Anti-Counterfeit agency (ACA) and other stakeholders, improved ACA capacity and better collaboration will enhance reporting and aid curb trade in counterfeits. Additionally, perception of victims towards the police or other agencies positively impacts the reporting behavior of consumer fraud. Poor perception towards the police impacts consumer fraud reporting significantly which means improving how citizens perceive the police is important in fighting the consumer fraud problem. An improved perception will create confidence in the security systems and people will be willing to file reports about economic crimes such as consumer fraud. Initiatives of reforming the police to improve service delivery should be encouraged while also embracing their capacity building on consumer crimes to enhance reporting and response.
\end{abstract}

Keywords: Consumer Fraud, Reporting, Counterfeits, Kenya 


\section{Background}

Fraud is defined as knowing misrepresentation of the truth or concealment of material facts to induce the victim to act to their detriment (Holtfreter, et al 2005). In general a fraud is an act of dishonesty that leads to deceit of the victim with an intention of benefiting at the expense of the deceived. Fraud occurs in various forms which include but are not limited to: bank fraud that comprises of forged documents such as cheques, letters of credit, and letters of instruction; theft of cash and goods; procurement fraud that involves over invoicing and fabricated invoices; bribery; inaccuracy and non-declaration in customs and excise duty; tax evasion; forged cheques' signatures; false insurance claims; tender and contract fraud; electronic funds transfer fraud; and identity fraud. The effects of any form of fraud are detrimental and result into revenue loss both to government in form of taxes while individuals and corporations lose income.

Consumer fraud is a form of economic crime that involves deception of the victim with the promise of goods, services or other benefits that are non-existent or are grossly misrepresented (Holtfreter, et al 2005). There are various aspects of consumer fraud; according to the KPMG fraud survey of 2003 it includes; ATM theft, check and credit card fraud, fraudulent classification of merchandise for customers, fraudulent merchandise returns, and identity fraud. The Kenya crime victimization survey of 2010 categorizes consumer fraud into stolen or forged cheques which can also be referred to as financial fraud; fraudulent schemes such as pyramid schemes; payment of non-existent goods or services; and proliferation of counterfeit goods or provision of poor services.

Consumer fraud may occur in construction or repair work (mainly through substandard work); in hotels or restaurants (through poor services); in supermarkets, shops and chemists (through counterfeit goods); and over the internet or e-commerce (through fraudulent transactions such as cyber crime). Other avenues may be through poor services in the medical, financial, and learning institutions. Issuance or obtaining of academic certificates through fraudulent means amounts to academic fraud which is also a form of consumer fraud. In general, consumer fraud comprises a wide range of issues that affect and influence a consumer's daily operations.

Figure 1 presents the International Criminal Victimization Survey (ICVS) conducted in the year 2000 by United Nations Interregional Crime and Justice Research Institute (UNICRI). Consumer fraud though hoped to be less prevalent in Africa appears to be more common in the continent than any other place besides Eastern Europe. Nearly 30 per cent of Africans surveyed responded in the affirmative that they had been defrauded in the previous year. The higher levels in Europe could hypothetically be because most people are educated and therefore would tend to be open and report(Note 1) more consumer fraud to the authorities while the situation in Africa could imply that it is a dumping ground that is also characterized by low levels of education. The effects of consumer fraud are diverse depending on the type of fraud and may range from loss of income, road accidents, deaths, and ill health. 


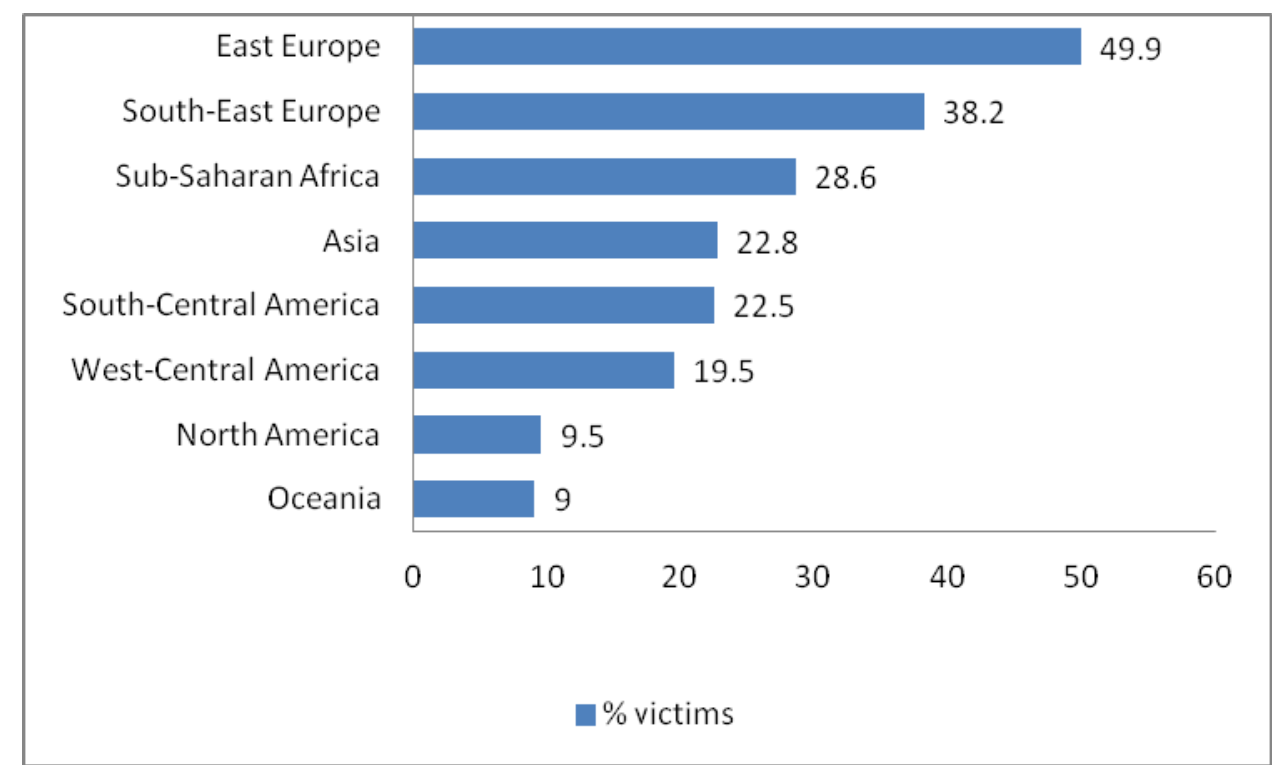

Source: UNICRI, ICVS 2000

Figure 1. Survey respondents who suffered fraud in the previous year

Financial fraud for instance affects both the consumers of financial services and the financial service providers. According to Deloitte East Africa's financial crimes survey report of 2013 close to 2.55 billion shillings was lost in the region to fraud by banks and insurance companies in the year 2013. Experts from Deloitte though estimate this figure to be much bigger than reported since most institutions under report to protect their reputation. Pyramid schemes victims in Kenya lost money, property, and developed chronic diseases resulting from depression. In some instances people committed suicide because of the associated losses. The report by the taskforce on pyramid schemes in 2010 indicates that close to 8.2 billion shillings was lost by victims in Kenya. These were however the estimated amounts in principle without factoring in expected returns. The taskforce in its report admits that these were initial figures and that the loss could be much more since all victims might not have come forth for registration by the time the report was released.

Additionally, proliferation of counterfeit products affects many sectors of the economy mostly in: motor vehicle assembly and its components sector; energy, electrical and electronic sector; food, beverages and tobacco sector; chemicals and allied sector and pharmaceuticals and medical equipment sector (KAM, 2012). The implications of counterfeit goods in the market are insurmountable and range from loss of revenue for manufacturers; loss of revenue to the government from taxes; adverse health effects caused by counterfeit foodstuffs; drugs and medical related equipments; increased insecurity resulting from counterfeit locks and increased road accidents caused by counterfeit motor vehicle parts such as tyres and brake pads. The Kenyan Association of Manufacturers (KAM) estimated in 2012 that the East African region loses about US\$ 500 million on counterfeit products. In addition, KAM estimates that more than 30 per cent of medicines sold in the Kenyan market are counterfeit. Kenyan manufacturers lose over 30 billion shillings per year while the government loses 6 billion shillings per year in revenue due to counterfeits(Note 2). 
A lot of attention with respect to reporting, enforcement and policy has focused on violence and property crimes victimizations (Mustaine\&Tewskbury 2000; Tseloni 2000); while economic crimes against consumers have received little attention despite their adverse socio-economic effects. This could be explained by the unavailable (scanty) data on consumer related crimes (Kusic, 1989; Moore and Mills 1990; Titus et, al, 1995). Another cause could be the failure to report such cases by the affected people. While consumer fraud is clearly a public policy issue that requires attention from researchers and policy makers, the focus of legislation and victim assistance programs has been on victims of violent and property crimes. The need to address issues of consumer fraud by policy makers is therefore paramount. To this front, the Kenyan situation has not been different; which validates the attempts of this research to profile a comprehensive understanding of consumer fraud victimization and likely factors affecting reporting of these crimes in Kenya.

\subsection{Situational Analysis of Consumer Fraud in Kenya}

Consumer fraud in its nature tends to represent acts of omission or commission against consumer protection attempts. Article 46 of the Constitution of Kenya provides an elaborate understanding of consumer rights under which consumer fraud activities undermine. Some of the rights articulated in the Constitution that enhance consumer protection include: right to goods and services of reasonable quality; right to information which aids the consumers to gain full benefits from goods and services, protection of health, safety and economic interests; and right to compensation for loss or injury arising from defects in goods and services. Apart from the Constitution, issues of consumer protection are also elaborated in the Competition Act of Kenya Cap 504 which provides for consumer representation and protection with a well outlined redress mechanisms in case of violations. Another regulatory milestone on issues of consumer protection in Kenya was the enactment of the Consumer protection Act number 46 of 2012 by the national assembly. The Act guarantees the consumers fundamental rights protecting them from false and misleading practices. Other pieces of legislation that advocate for issues of consumer protection include but are not limited to; Fertilizers and Animal Foodstuffs Act Cap 345 that guarantees consumer safety by prohibiting the use of fertilizers and foodstuffs that have either bone or other animal matter containing disease causing organisms in the production of fertilizers.

The Weights and Measures Act Cap 513 safeguards consumers against sale of goods with inaccurate quantities; the Food, Drugs and Chemical Substances Act Cap 254 guards against the sale of unwholesome, poisonous or adulterated food to consumers; the Trade Descriptions Act Cap 505 enhances honesty in business deals and deter false or misleading statements regarding various aspects of goods that involve their identity, quantity, size, gauge, and method of production. The Standards Act Cap 496 aims to guard against substandard and unsafe products and is enforceable by the Kenya Bureau of Standards (KEBS); the Sale of Goods Act Cap 31 outlines the provisions for a sales contract between consumers and sellers of goods and services; the Medical Practitioners and Dentists Act Cap 253 ensures that those who engage in the medical practice are qualified and can be relied upon by the consumers; and the Economic Crimes Act of 2003 which prohibits intentional falsification or manipulation of information in order to confer benefits to oneself or other person(s) through 
dishonesty, deceit or trickery. The Trademark Act Cap 506 prohibits importation, making, selling or trading in goods that have been forged, replicated or uses a registered trademark that is likely to deceive or cause confusion to the consumers. Additional pieces of legislation include: the Customs and Excise Act Cap 472 which prohibit misrepresentation of trademarks, business names or addresses; the Pharmacy and Poisons Act Cap 244 ensures that drugs have correct ingredients and are not falsely advertised or mislabeled; while the Alcoholic Drinks Act number 4 of 2010 prohibits sale of adulterated alcohol and protects the consumers from deceptive inducements.

Under the financial sector the Capital Markets Authority (CMA) through the Capital Markets Act Cap 485A is mandated to undertake protection of investor interests to avoid financial losses arising from the failure of a licensed broker or dealer to meet their contractual obligations. On the other hand the Insurance Act Cap 487 mandates the Insurance Regulatory Authority to protect the interests of insurance policy holders and beneficiaries in any insurance contract. The Banking Act Cap 488 establishes the Deposit Protection Fund Board whose principal objective is to provide a deposit insurance scheme for customers of member institutions. This is aimed at protecting the customers in case a member financial institution becomes insolvent and is liquidated. Consumer protection also takes place in the telecommunications sector with the Kenya Information and Communications Act Cap 411A mandating the Communication Commission of Kenya (CCK) to protect interests of all telecommunication users in terms of prices, quality and variety of services offered. The commission also maintains and promotes effective competition in the sector to ensure efficiency in service provision.

In the energy sector, the Energy regulatory commission (ERC) is established under the Energy Act Cap 314 and is mandated to protect the interests of consumers, investors and other stakeholders among other functions. The water Act Cap 372 establishes the Water Services Regulatory Board (WASREB) which determines standards of water services and ensures efficient, affordable, and sustainable services to consumers among other duties. A review of the Anti-Counterfeit Act Cap 130A shows that the Anti-Counterfeit Agency (ACA) engages largely in consumer welfare and protection activities which range from combating counterfeits to creating awareness on matters of counterfeiting in Kenya among others. The mandate of the agency is inclined to the intellectual property right holders. An investigation about a violation can only be instituted by the agency if an intellectual property holder reports it. The agency can also institute investigations into a violation if it deems necessary to do so. Generally, there is no incentive for the intellectual property holder to report a violation to the agency.

While the Act has a provision on consumer protection, it does not provide information on avenues of reporting or redressal for consumers affected by counterfeits. This is inconsistent with the consumer protection Act number 46 of 2012 which identifies reporting as an important ingredient in enabling consumers get redress in case of any violation. ACA also lacks a national presence with offices located only in Nairobi and Mombasa; furthermore the officers are incapacitated with the Nairobi and Mombasa offices having six and two enforcement officers respectively. This hinders reporting for the victims who might want to 
physically file a complaint. The lack of a national presence and adequate staffing is a probable indicator that the agency lacks enough financial capacity to run its activities in the fight against the vice.

There are various institutions engaged in consumer protection in specific sectors of the economy in Kenya. The umbrella body charged with the role of supervision and coordination of other regulatory agencies on issues of competition and consumer protection is the Competition Authority of Kenya (CAK). Advocacy institutions that drive the consumer agenda include; Consumer Federation of Kenya (COFEK) and Consumer Unity and Trust Society (CUTS). Despite the existence of a regulatory framework for articulating consumer protection issues, the levels of consumer fraud reporting are low in Kenya. According to the State of the Kenyan Consumer 2012 report by CUTS, there exists a lack of awareness on redressal mechanisms by the Kenyan consumers. The Kenya Crime Victimization Survey done by KIPPRA and United Nations Office on Crimes and Drugs (UNODC) in 2010, indicated that out of the 644 cases of consumer fraud encountered, only 4.6 percent were reported to either the police or other agencies (authorities).

\section{Literature Review}

\subsection{Theoretical Literature}

Reporting of any form of crime to the police or any other authorities has evolved because of its important role in the criminal justice system. Studies suggest that those who report crime to the police are interested in safeguarding the criminal justice system (Black, 1971; Hindelang, 1976). This study will be based on the three correlates that influence crime reporting as postulated in Zhang et al, 2007 which comprises of the victim specific variables that consists of individual or household attributes; incident specific variables; and environment specific variables. The victim specific variables encompass demographic characteristics attributed to personal victimization which include gender, race, age, and education (Hindelang and Gottfredson, 1976; Skogan, 1984). On the other hand household characteristics include number of members in the household and the income of the household.

The incident specific variables address the features of the criminal event which may include injury, monetary loss and the victim-offender relationship (Gottfredson and Hindelang, 1979; Skogan, 1984). The environment specific variables investigate majorly the effects of neighborhood characteristics such as neighborhood disadvantage and social cohesion (Baumer, 2002). Two theories that have been developed on issues of crime reporting are advanced in Zhang et al, 2007. These theories though at their infancy stages have been tested empirically by Zhang et al, 2007 on property and personal related crimes. The field of consumer fraud is grey as far as theoretical frameworks are concerned and as a result this study will employ the theories developed in the areas of property and personal related crimes in its attempt to establish the reasons behind the low levels of reporting of consumer fraud related crimes in Kenya. 


\subsubsection{General Rational Choice Theory}

This theory was advanced by Skogan, 1984; Gottfredson and Gottfredson, 1987 and Felson et al, 2002. According to this approach the victims weigh the potential benefits and costs to be incurred when considering whether to file a complaint about a criminal incident with the police. In most of the cases the benefits of filing a complaint include the victims drive to have the offenders brought to justice through punishment; protection of the victims and potential victims from future victimization (Felson et al, 2002). In the instances of property crimes, the benefits of reporting crimes are also based on the anticipation of recovery of stolen goods. People may however fear to report crimes because of fear of reprisal from the offenders, embarrassment at having been victimized, fear of reprisal from others in groups where cooperation with governmental officials is looked down upon (Zhang et al, 2007). Another challenge may be the long adjudication process which may discourage victims from reporting serious crimes (Felson et al, 2002).

\subsubsection{Sociological Theory of the Behavior of Law}

This theory was advanced by Donald Black in 1976. According to this approach law is defined as government social control which is interpreted to mean a call or visit to the police, regulatory agency or a lawsuit. The quantity of law varies across time and space (across societies, regions, communities, neighborhoods, families and relationships). Black's theory carries implications for each of the three types of correlates of reporting; victim specific, incident specific, and neighborhood specific. The theory brings forth various hypotheses which provide basis for the three correlates of reporting. The first hypothesis in the theory is that crime reporting is related to the socio-economic status of the victim. Under this hypothesis lower ranks have less law than higher ranks which means that people of higher socio economic status are likely to report crimes more than people of low status.

The second hypothesis advanced by the theory is based on the relational distance on the quantity of law. Relational distance is said to be negatively related to law whereby closer relationship between the victim and offender means that crime incidents are less likely to be reported. On the other hand the third hypothesis is about the 'radial location' concept where level of social integration is positively related to law. This implies that people who are more integrated to mainstream society are more likely to report crimes than those who are less integrated. According to this hypothesis, employed people are more integrated in society than the unemployed people; married people are more integrated than the single people; hence employed people and married people are more likely to report crimes to the authorities than otherwise.

To be able to study the effects of neighborhood disadvantage, Black (1976) brings forth two theories: social stratification and social control which provide some rationale for this. Under social stratification Black, postulates that law varies with the proportion of the population that is more or less wealthy. This implies an effect of community socioeconomic conditions on crime reporting. In this case people of higher socio economic standings are expected to report crimes more often than people of low wealth status. On the other hand, law varies inversely with social control which is the normative aspect of social life. Law is said to be less 
important as a mechanism of social control since people are permitted to react to each other's conduct in a social context. The level of neighborhood social cohesion and informal control is therefore expected to be negatively related to crime reporting.

\subsection{Empirical Literature}

Empirical literature on factors determining consumer fraud reporting is limited just as the theoretical literature with a majority of the available information dwelling much on personal and property crimes. Goldberg and Nold (1980) from whose work these study borrows the analytical framework advances that the probability of reporting burglary depends on the loss involved, property damaged and the cost of reporting. The study uses the logit model and establishes that reporting which is a victim specific self protection mechanism deters burglary victimization. MacDonald (1998) follows the same analytical framework while addressing underreporting of property crime in Britain using the probit model and establishes that unemployment reduces the probability of reporting burglary. While these may not be directly related to this study they provide a good analytical framework for consumer fraud crime reporting hence are worth being reviewed.

Most of the studies on consumer fraud have focused on the factors determining victimization. Anderson (2006), while looking at the effect of demographics on identity theft in the United States of America using a multivariate probit regression concludes that the risk of identity fraud generally appears to be related to demographics. Those with higher incomes are more likely to be victims of identity fraud. Older people on the other hand face a reduced risk of identity fraud victimization than younger people. A household with one adult and more children leads to increased identity fraud victimization. In addition, women are more likely to be victimized than men.

Ippolito and Mathios (1989), while studying health claims in advertising and labeling of the cereal market in the United States of America using both probit and tobit regression methodologies suggest that more education of the consumers amounts to increased awareness. Educated people have a lower risk of identity theft crime victimization. This is also supported by McGhee, 1983; and Jinkook and Horacio, 1997. McGhee (1983) establishes that higher educational attainment improves the coping abilities of the elderly people to fraud while Jinkook and Horacio (1997), using ordered logit regression in the USA determine that less educated consumers are more vulnerable to consumer fraud. A contrasting finding is advanced by Titus et al, 1995 who establishes that younger as well as educated people are victimized more often by personal fraud in the USA. This is surprising since education seems not to provide a protective cover expected from this type of crime generally characterized as being a battle of the mind. Jinkook and Horacio (1997), also establish that age, marital status and income also influence consumer vulnerability.

Macdonald (1998) and Zhang et al (2007) establish that offense seriousness is a significant predictor of reporting for both property and personal crimes. The former uses the probit regression method from the British Crime Victimization survey data for the years 1994 and 1996 while the latter uses a logistic regression method from the criminal victimization data for Tanjin, China in 2004. Zhang et al (2007) also notes that victimization experience which 
is an individual specific variable has a negative effect on reporting of robbery /assault when other factors are controlled. The negative effect could imply that the victims are less hesitant to turn to the police as victimization increases. On the other hand Macdonald (1998) finds out that the probability of reporting is decreased if the victim is currently unemployed.

Both regionally and locally, there is little documented evidence on consumer fraud let alone on reporting of consumer related crimes. According to a financial crimes survey report by Deloitte in 2013, the most prevalent financial crimes(Note 3) in the East African region are cash theft, cheque fraud and asset misappropriation. Most of these crimes are committed as a result of weak internal control systems which are incident specific factors. On reporting, financial organizations prefer to understate figures on losses and majorly deal with those crimes experienced internally without raising eyebrows to prevent negative effects of reduced investor confidence on their performance in the market.

\section{Methodology}

\subsection{Model Specification}

Goldberg and Nold (1980) models the household's probability of reporting a crime as a function of the loss involved, property damage, and the cost of reporting. Reporting of a crime may however vary depending on individual attributes, experiences and personal circumstances specific to that incident. According to MacDonald (1998) the model can be represented as follows;

$\operatorname{Pr}($ reporting $)$

$=f$ (incident involves loss, socioeconomic factors, incident specific factors, attitudes to the police). 1

This can be expressed as follows;

$\operatorname{Pr}($ reporting $C F)$

$$
\begin{aligned}
& =\beta_{0}+\beta_{1} G E N_{i}+\beta_{2} L O C_{i}+\beta_{3} E D U_{i}+\beta_{4} M A R_{i}+\beta_{5} T Y P_{i}+\beta_{6} V A L_{i}+\beta_{7} P E R_{i} \\
& +\beta_{8} N O H_{i}+\beta_{9} I N C_{i}+\beta_{10} O C C_{i}+\beta_{11} A G G_{i}+\varepsilon_{i} \ldots \ldots \ldots \ldots \ldots \ldots \ldots \ldots . . \ldots \ldots \ldots \ldots \ldots
\end{aligned}
$$

Where $\varepsilon_{i}$ represents the error term and CF is consumer fraud.

\subsection{Estimation Technique}

An individual's tendency to report a crime is not observable rather we observe the reporting outcome for each specific incident which is a binary outcome: either reported or not. These can therefore be estimated through either; logit, probit or linear probability model (LPM). This study adopts a logit model in determining the factors determining reporting of consumer fraud victimization in Kenya. While the study takes cognizance of the fact that either LPM or probit models could be used in analysis, there are certain weaknesses associated with the two. For instance LPM which is similar to ordinary least squares regression though applied to a binary dependent variable has several weaknesses: LPM has a heteroskedastic error term which leads to biased estimates and its fitted probabilities may lie outside the $0-1$ range. The preference for the logit model follows the assumption of the distribution of the error term 


\section{Macrothink

which follows a logistic distribution. While the distribution of the error term for a probit model follows a normal distribution. Both distributions of the error term are similar in shape though the logistic distribution has a heavier tail (higher kurtosis) than the normal distribution which increases the robustness of the analysis. Since the dependant variable is binary in nature, the probability of reporting a consumer fraud crime to either the police or any other agents is coded as 1 or 0 otherwise. It is convenient to use $A$ and $\lambda$ to express the cumulative density function (cdf) and probability density function (pdf) respectively of a logit distribution. The pdf is expressed as;

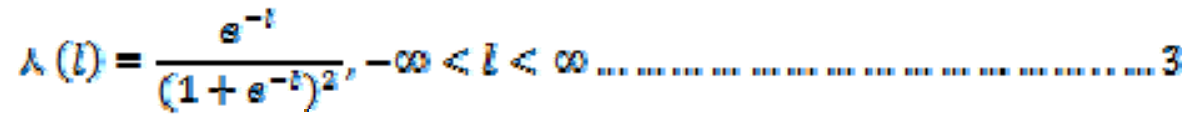

The cdf is expressed as;

$$
p=p\left(l \leq x_{i}^{t} \beta\right)=\frac{1}{1+e^{-\left(x_{i}^{t} \beta\right)}} \ldots \ldots
$$

Then $\operatorname{Pr}\left[\mathrm{y}_{i}=1 / \mathrm{x}_{i}\right]$ and $\operatorname{Pr}\left[\mathrm{y}_{4}=\boldsymbol{\theta} / \mathrm{x}_{1}\right]$ which represent whether a consumer fraud is reported to the police or other authorities and otherwise respectively can be expressed as;

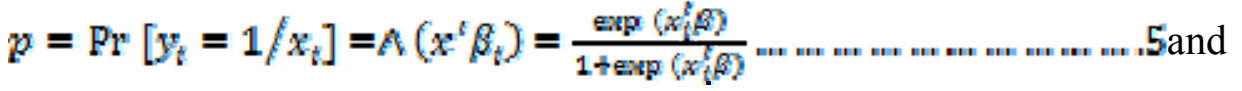

$$
\begin{aligned}
& 1-p=\operatorname{Pr}\left[y_{t}=0 / x_{i}\right]=1-A\left(x^{t} \beta_{i}\right)=1-\frac{\exp \left(x_{i}^{t} \beta\right)}{1+\exp \left(x_{t}^{t} \beta\right)}=\frac{1}{1+\exp \left(x_{t}^{l} \beta\right)} \ldots \ldots
\end{aligned}
$$

Equation 5 represents the probability of reporting a consumer fraud to the police or other authorities by a victim, while equation 6 represents the probability of not reporting.

The marginal effects are derived from equation 5 where interpretation for both sign and significance is important. Equation 5 is differentiated to give the marginal effects as follows;

$$
\frac{\partial p\left[\frac{y_{t}}{x_{i}}\right]}{\partial x_{t}}=\left\{A\left(x^{t} \beta_{t}\right)\left[1-A\left(x^{t} \beta_{t}\right)\right] \beta_{t} \ldots \ldots\right.
$$

The odds ratio is given by $\frac{\gamma_{i}}{1-p_{t}}=\exp \left(x_{t}^{k} 72\right)$ while the log odds ratio or logit is given by;

$$
\ln \left[\frac{\eta_{t}}{1-\eta_{l}}\right]=x_{t}^{t} \beta_{1}
$$


Equation 8 can also be expressed as

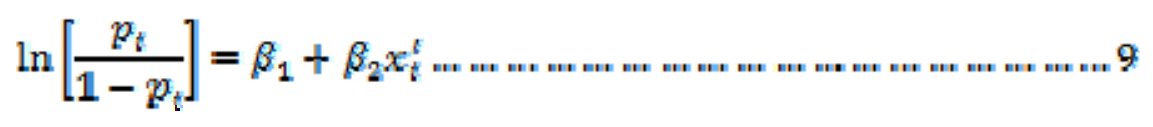

Where $\beta_{1}, \beta_{2}$ represent parameter vectors while $x_{i}^{i}$ represent explanatory variables which are individual specific, incident specific and neighborhood specific. Equation 9 can be transformed into the following using the explanatory variables in equation 2 above;

$$
\begin{aligned}
& \ln \left[\frac{\operatorname{Pr}(\text { report CF }=1)}{\operatorname{Pr}\left(\text { dont report } C F^{\prime}=0\right)}\right] \\
& \quad=\beta_{0}+\beta_{1} G E N_{t}+\beta_{2} L O C_{t}+\beta_{9} E D U_{t}+\beta_{4} M A R_{t}+\beta_{5} T Y P_{t}+\beta_{6} V A L_{t} \\
& \quad+\beta_{7} P E R_{t}+\beta_{9} N O H_{t}+\beta_{9} I N C_{t}+\beta_{10} O C C_{t}+\beta_{11} A G G_{t} \ldots \ldots
\end{aligned}
$$

The logit model is a fully linear function of the explanatory variables, $\mathrm{x}$ and uses the maximum likelihood estimation technique which maximizes the likelihood of an event occurring.

\subsection{Data and Variables Specification}

The study utilizes cross sectional data obtained from the Crime Victimization Survey conducted by KIPPRA in collaboration with the United Nations Office on Drugs and Crime in 2010. This was a national survey which targeted a sample of 3000 households through which individuals were accessed and interviewed. The sampling process was carried out by the Kenya National Bureau of Statistics (KNBS) using the National Sample Survey and Evaluation Program- NASSEP IV. An initial sample of 162 rural and 138 urban clusters spread in all the 67 districts in Kenya was drawn. The households were sampled systematically with a random start. No replacement was to be allowed for 'away' or relocated households. This was because the specific households were drawn using the name and number of household as in the frame. However, due to cost implications the districts were narrowed down to 30 with 10 households from each cluster. The variables are defined in table 1 below. 


\section{Macrothink}

Table 1. Variables definitions and measurements

\begin{tabular}{|c|c|c|c|}
\hline Variable & Description of variable & Measurement of variable & $\begin{array}{l}\text { Apriori } \\
\text { expectation }\end{array}$ \\
\hline Report & $\begin{array}{l}\text { Reporting of consumer } \\
\text { fraud to the police or any } \\
\text { other agency }\end{array}$ & $\begin{array}{l}\text { Dichotomized variable representing } \\
\text { whether a consumer fraud victim } \\
\text { reports to either the police or any other } \\
\text { agency (1) or otherwise }(0)\end{array}$ & - \\
\hline GEN & Gender of the respondent & $\begin{array}{l}\text { Dummy variable }(1 \text { if male, } 0 \\
\text { otherwise) }\end{array}$ & Indeterminate \\
\hline LOC & Location of the respondent & $\begin{array}{l}\text { Categorical variable ( } 1 \text { if rural, } 2 \text { if } \\
\text { urban) }\end{array}$ & Indeterminate \\
\hline EDU & $\begin{array}{l}\text { Education level of the } \\
\text { respondent }\end{array}$ & Categorical & $\begin{array}{l}\text { Positive } \\
\text { relationship: higher } \\
\text { education means } \\
\text { likelihood to report }\end{array}$ \\
\hline MAR & $\begin{array}{l}\text { Marital status of the } \\
\text { respondent }\end{array}$ & Categorical & Indeterminate \\
\hline TYP & $\begin{array}{l}\text { Type of the consumer fraud } \\
\text { that the respondent } \\
\text { experienced }\end{array}$ & Categorical & Positive \\
\hline VAL & $\begin{array}{l}\text { Value lost by the respondent } \\
\text { in Kenya shillings }\end{array}$ & Continuous & Positive \\
\hline PER & $\begin{array}{l}\text { Perception of the victims } \\
\text { about the police' ability to } \\
\text { control crime }\end{array}$ & Categorical & Positive \\
\hline $\mathrm{NOH}$ & $\begin{array}{l}\text { Number of members in the } \\
\text { household }\end{array}$ & Continuous & Indeterminate \\
\hline INC & Income of the victim & Continuous & Positive \\
\hline OCC & $\begin{array}{l}\text { Employment status of the } \\
\text { victim }\end{array}$ & Categorical & Positive \\
\hline AGG & Age group of the victim & Continuous & Indeterminate \\
\hline
\end{tabular}

\section{Empirical Results}

\subsection{Diagonostic Tests}

Reporting of consumer fraud to either the police or other agencies was modeled against eleven explanatory variables that influence reporting of consumer fraud. The underlying hypothesis is that the level of education, the value lost, type of fraud, perception of police about controlling crime, victim's income and employment status influence the decision to report a consumer fraud. The logistic regression model was evaluated for muliticollinearity using the variance inflation factor (VIF)(Note 4) as reported in table 2 below and heteroskedasticity using the white test(Note 5) as per table 3 . The variance inflation factor 


\section{Macrothink}

Research in Applied Economics

ISSN 1948-5433

2014, Vol. 6, No. 3

indicated that collinearity among the analyzed variables was not high. The null hypothesis for homoskedasticity as per table 3 was rejected which means the model contained the problem of heteroskedasticity. This was addressed by use of robust standard errors.

Table 2. Test for multicollinearity

\begin{tabular}{llll}
\hline Model & & Collinearity statistics \\
\hline & Variable & VIF & $1 /$ VIF (Tolerance) \\
EDU & 1.28 & 0.781 \\
LOC & 1.21 & 0.828 \\
VAL & 1.14 & 0.874 \\
INC & 1.12 & 0.894 \\
TYP & 1.04 & 0.959 \\
GEN & 1.17 & 0.856 \\
NOH & 1.07 & 0.935 \\
MAR & 1.46 & 0.686 \\
PER & 1.06 & 0.94 \\
OCC & 1.09 & 0.918 \\
AGG & 1.42 & 0.703 \\
\hline
\end{tabular}

Table 3. White heteroskedasticity test

White's test for Ho: homoskedasticity

Against Ha: unrestricted heteroskedasticity

$\operatorname{Chi} 2(75)=106.62$

Prob $>$ chi $2=0.0096$

Cameron \& Trivedi's decomposition of IM-test

\begin{tabular}{llll}
\hline Source & Chi2 & df & P \\
\hline Heteroskedasticity & 106.6 & 75 & 0.01 \\
Skewness & 61.91 & 11 & 0 \\
Kurtosis & 31.51 & 1 & 0 \\
Total & 200.1 & 87 & 0 \\
\hline
\end{tabular}




\subsection{Estimation Results}

Table 4. Estimation results

\begin{tabular}{|c|c|c|c|c|}
\hline Variables & Marginal effects & z-values & Odds ratio & z-values \\
\hline \multicolumn{5}{|l|}{ GEN (reference group is female) } \\
\hline Male & -0.0056059 & -0.64 & 0.7168431 & -0.65 \\
\hline \multicolumn{5}{|l|}{ LOC(reference group is urban) } \\
\hline Rural & 0.011874 & 1.28 & 1.973972 & 1.24 \\
\hline \multicolumn{5}{|l|}{$\begin{array}{l}\text { EDU (reference group is no } \\
\text { education/incomplete primary) }\end{array}$} \\
\hline Primary & -0.0075588 & -0.84 & 0.611303 & -0.76 \\
\hline Secondary & -0.0063293 & -0.65 & 0.6755076 & -0.61 \\
\hline University & -0.0046019 & -0.45 & 0.7434659 & -0.42 \\
\hline \multicolumn{5}{|c|}{$\begin{array}{l}\text { TYP (reference group is paid for nonexistent } \\
\text { services/goods or stolen forged/forged cheque }\end{array}$} \\
\hline Given fake goods/poor services & $-0.0351567 * *$ & -2 & $0.218075^{* * *}$ & -2.69 \\
\hline Fraudulent schemes and others & -0.0084102 & -0.98 & 0.5659001 & -0.96 \\
\hline \multicolumn{5}{|l|}{ VAL (reference group is $0-1000$ ) } \\
\hline $1001-10000$ & $0.0232905^{*}$ & 1.73 & $2.805716^{* *}$ & 1.98 \\
\hline $10001-100000$ & 0.1231821 & 1.49 & $9.732772 * * *$ & 2.95 \\
\hline $100001-1500000$ & $0.6655339 * * *$ & 3.21 & $126.3791 * * *$ & 4.92 \\
\hline \multicolumn{5}{|l|}{ PER (reference group is very good job) } \\
\hline Fairly good job & 0.0225064 & 0.78 & 3.127203 & 0.94 \\
\hline Fairly poor job & 0.0433323 & 0.85 & 4.910864 & 1.35 \\
\hline Very poor job & 0.1099935 & 1.11 & $12.84388 * *$ & 2.19 \\
\hline \multicolumn{5}{|l|}{ INC (reference group is $0-<50000$ ) } \\
\hline \multicolumn{5}{|l|}{$>=100000$} \\
\hline \multicolumn{5}{|l|}{ MAR (reference group is single) } \\
\hline Married/living as a couple & -0.0022492 & -0.19 & 0.8798812 & -0.2 \\
\hline Divorced/separated or widow/widowed & -0.0144881 & -1.54 & 0.2627063 & -1.04 \\
\hline \multicolumn{5}{|l|}{ NOH (reference group is 1 to 3 ) } \\
\hline 4 to 6 (medium) & 0.0101909 & 0.98 & 1.794272 & 1.11 \\
\hline 7 to 10 (large) & -0.0025396 & 0.17 & 1.151704 & 0.18 \\
\hline \multicolumn{5}{|l|}{ OCC (reference group is working) } \\
\hline Looking for work (unemployed) & 0.0091705 & 0.52 & 1.5656 & 0.62 \\
\hline Keeping home, or retired, disabled & -0.0127575 & -1.44 & 0.4044933 & -1.49 \\
\hline Going to school /college or other & -0.0106147 & -1.52 & 0.4781848 & -1.22 \\
\hline \multicolumn{5}{|l|}{ AGG (reference group is $<=25 \mathrm{yrs}$ ) } \\
\hline $26-35 \mathrm{yrs}$ & 0.0136711 & 0.9 & 2.007201 & 0.95 \\
\hline $36-55 \mathrm{yrs}$ & 0.0033536 & 0.22 & 1.207642 & 0.22 \\
\hline$>55 \mathrm{yrs}$ & 0.0421268 & 1.12 & $3.99645^{*}$ & 1.77 \\
\hline Number of Observations (N) & 624 & & 624 & \\
\hline eudo $R^{\wedge} 2$ & 0.2419 & & 0.2419 & \\
\hline
\end{tabular}

*significant level at $10 \%$ level; ** significant level at $5 \%$ level; *** significant level at $1 \%$ level 
From table 4 results, the level of education of the consumer does not seem to influence the reporting of consumer fraud. This even though surprising is consistent with the findings of Titus, et al (1995) on issues of personal fraud. This therefore means that both educated and non educated people stand a chance of failing to report consumer fraud once they become victims. Income levels of the victims also do not influence reporting of consumer fraud which is not consistent with the social stratification strand in Black's theory of the behavior of law. The victims who are well of as far as income levels are concerned do not seem to report consumer fraud more often than their counterparts who are of lesser income levels. The marital status which is postulated in the third hypothesis of Black's sociological theory of law under the radial location concept as a determining factor of crime reporting fails to be important. Other independent variables that are not important include location, gender, employment status and the size of the family in terms of the number of household members.

The type of consumer fraud appears to influence the reporting behavior specifically fraud that occur with respect to counterfeit products or provision of poor services. From the results; the direction of the relationship between reporting and the type of consumer fraud is negative implying that a marginal change in type of crime as far as counterfeits or poor services are concerned will lead to a decrease in the rate of consumer fraud reporting to the authorities. The result is statistically significant at 5 per cent with the marginal effects showing that an increase in the proliferation of fake goods in the market by one unit reduces the probability of reporting consumer fraud to the authorities by 3.5 per cent from the mean $(0.6458)$. This finding apart from being consistent with the incident specific correlate of reporting crime also lends insightful information to combat counterfeits in the country with results showing that the more the people become victims the less they are likely to report such crime to the authorities.

Value lost by the victims also positively impacts the reporting behavior, especially with victims who lose large sums of money in consumer fraud likely to report more than those who lose less significant sums. The result is statistically significant at 1 per cent with the marginal effects showing that an increase in the amount of money lost in consumer fraud by one unit will increase the probability of reporting the crime by 67 per cent from the mean (0.0096). This finding is in agreement with the incident specific correlate with the value lost in a consumer fraud being a determining factor as to whether the crime will be reported or not. It also agrees with the findings of Macdonald, 1998 and Zhang et al, 2007 who establish that offense seriousness is a significant predictor of reporting for both property and personal crimes.

The perception of the victims to the police and other authorities positively impacts the reporting behavior of consumer fraud. However poor perception of the victims towards the police and other authorities seems to impact consumer fraud reporting more at 5 per cent significance level. The marginal effects are however positive but insignificant. On examining the odds ratio we conclude that for every change in perception about the police and other authorities' performance in combating any form of crime, the odds of reporting crime improves by 12.8 per cent holding other factors constant. This finding is consistent with Goldberg and Nold (1980) modeling of crime reporting as a function of the attitudes to the 
police. The finding therefore lends a lot of credence to the government efforts of reforming security agencies to tackle crimes effectively.

These reforms of the security agencies specifically the police will increase the citizens' confidence in the systems and improve levels of consumer fraud reporting. The age group of the victim is also important in explaining consumer fraud reporting on examining the odds ratio. People who are above 56 years have improved odds of reporting consumer fraud by 4 per cent holding other factors constant. This could be attributed to the fact that older people are wiser and careful in decision making than younger ones. For instance older people are careful not to engage in risky investment ventures in anticipation for higher returns compared to the younger generations who have a higher affinity for quick money and shortcuts becoming likely victims of consumer fraud.

\section{Conclusions and Recommendations}

\subsection{Conclusions}

There is limited research on consumer fraud in Kenya despite the negative socio-economic costs associated with it. Despite the socio-economic costs, victims are less interested to report these crimes to the authorities as per the findings of the crime victimization survey of 2010 in Kenya. This research is therefore an attempt to put this subject into perspective and understand why victims do not report the crimes to the authorities. Demographic, incident specific and neighborhood indicators are examined to determine their effects on reporting of consumer fraud.

Descriptive results (see appendix 1) show that the most common consumer fraud in Kenya is the proliferation of counterfeit goods or provision of poor services which mainly occur in shops of some sort. The influx of counterfeit goods is therefore a policy challenge and the war against them by the government must be sustained if not improved since they are most prevalent and poses serious danger as relates to consumer fraud. In addition, the study establishes that proliferation of counterfeit goods is the crime that is most reported to the security agencies though in total reporting is low. This could be attributed to the fact that most of the consumer fraud experienced by victims in the survey comprised of proliferation of counterfeit goods. Other consumer fraud experienced as per the survey include fraudulent schemes; payment of non-existent goods or services; and stolen financial instruments and forged cheques.

Results from the study show that the type of consumer fraud (specifically counterfeit products or provision of poor services) influences the reporting behavior of victims. Victims who buy counterfeits repeatedly or receive poor services do not seem to be interested in reporting it to the authorities. This may imply lack of awareness on the rights and privileges of consumers when faced with counterfeit goods and services. The more they experience these crimes, the more they fail to report. This permissive attitude from the victims act as deterrence to the fight against counterfeits in the country. While levels of consumer awareness on what constitutes counterfeits may be a concern, the survey done in 2010 
showed that most consumers were in a position to distinguish between counterfeits and non counterfeit goods. More sensitization work can however be done to increase awareness amongst the consumers. High poverty levels may also be a probable indicator of low levels of reporting. Campaigns against counterfeits need to be stepped up both by government agencies such as the anti-counterfeit agency, Kenya Revenue Authority, Pharmacy and Poisons Board, Kenya Bureau of Standards; and Non-Governmental Organizations involved in consumer protection and advocacy. The awareness campaigns should also place emphasis on the reporting avenues; where and how to report based on the type of offence.

Perception about the police performance in controlling crime influences the reporting of consumer fraud by victims with those who believe they are doing a poor job less likely to report consumer fraud to them. This implies that there is need to improve confidence in the police service to foster crime reporting. A negative perception about the police deters consumer fraud (crime) reporting and hinders the fight against these vice.

\subsection{Policy Recommendations}

The study findings suggest that the most prevalent consumer fraud in Kenya involves proliferation of counterfeit goods and the provision of poor service to the clients. This brings into perspective the fact that the fight against counterfeits remains a major challenge in the country. This fight should therefore be sustained in momentum if not improved to deal with the growing trend of counterfeit commodities in the market place. To sustain this war, firstly there is need to review the ACA Act in order to address issues of consumer reporting. This will create consistency with the consumer protection Act number 46 of 2012 which identifies reporting as an important ingredient in enabling consumers get redress incase of any violation. Secondly, the Anti- Counterfeit Agency should be strengthened in terms of capacity. More financial resources should be allocated to the agency to enable it hire more personnel and widen its presence across the country. A widened presence will ease consumer access to the ACA officers and enhance reporting.

Thirdly, the agency needs to carry out awareness campaigns through the available communication channels such as the radio, television sets, newspapers, posters and bill boards, internet, and mobile phones. The campaigns should be directed at creating awareness on; ability for the consumer to differentiate counterfeits from original goods, the dangers exposed to in consuming counterfeits, and the reporting mechanisms available in case of victimization. Herein, the agency should embrace a digital reporting platform through the mobile phones and the internet for consumers. The awareness should also emphasize on how and where to report based on the type of offence. For instance counterfeiting should be reported to the agency while issues of false advertising should be reported to the Competition Authority of Kenya.

Fourthly, there is need for collaboration between various agencies engaged in fighting counterfeits. These agencies include; the Kenya Bureau of Standards, the Kenya Revenue Authority, the Anti-Counterfeit Agency, and the Pharmacy and Poisons Board. These multiple agencies can be harmonized through establishing a common complaints platform. This can either be an internet or Short message service platform which would enhance intelligence 
gathering, sharing and enforcement.

Similarly the study finds that negative perception by the public towards the police influence the reporting behavior of the victims of consumer fraud. Genuine attempts to improve service delivery by the police to the populace will improve public perception and confidence. The ongoing police reforms should therefore be sustained and fast tracked to improve reporting of crime, which includes consumer fraud. There is also need to capacity build the police on consumer crimes to facilitate response and enhance reporting.

\section{References}

Anderson, B. A. (2006). Who are the victims of identity theft? The effects of Demographics. Journal of Public Policy and Marketing, 25(2), 160-171.

Baumer, E. (2002). Neighborhood disadvantage and police notification by victims of violence. Criminology, 40, 579-616. http://dx.doi.org/10.1111/j.1745-9125.2002.tb00967.x

Black, D. J. (1971). The social organization of arrest. Stanford Law Review, 23, 1087-111. http://dx.doi.org/ 10.2307/1227728

Black, D. J. (1976). The Behavior of Law. New York: Academic Press.

Consumer Unity and Trust Society International (2012). State of the Kenyan Consumer report. Nairobi.

Deloitte (2013). Financial Crimes Survey Report; where is the exposure? East Africa: Deloitte.

Felson, R. B., Messner, S. F., Hoskin, A., \& Deane, G. (2002). Reasons for reporting and not reporting violence to the police. Criminology, 40, 617-648. http://dx.doi.org/10.1111/j.1745-9125.2002.tb00968.x

Goldberg, I., \& Nold, F. C. (1980). Does reporting deter burglars? An empirical analysis of risk and return in crime. Review of Economics and Statistics, 62, 424-431. http://dx.doi.org/10.2307/1927110

Gottfredson, M. R., \& Gottfredson, D. M. (1987). Decision making in criminal justice: Towards the rational exercise of discretion (2nd ed.). New York: Plenum Press.

Government of Kenya (Various). Laws of Kenya. Nairobi: Government printer.

Government of Kenya (2010). Constitution of Kenya (2010). Nairobi: Government printer.

Greene, W. H. (2002). Econometric Analysis (5th ed.). New York: Macmillan.

Hindelang, M. J. (1976). Criminal victimization in eight American cities: A descriptive analysis of common theft and assault. Cambridge, MA: Balinger. 
Hindelang, M. J., \& Gottfredson, M. (1976). The victim's decision not to invoke the criminal justice process. Criminal justice and the victim (William F. McDonald.). Beverly Hills, CA: Sage.

Holtfreter, K., Reisig, M. D., \& Blomberg, T. G. (2005). Consumer Fraud Victimization: An empirical study. Thomas L. Rev., 18, 791.

Ippolito, P. M., \& Mathios, D. A. (1989). Health claims in advertising and labeling: A study of the cereal market. FTC: Bureau of Economics staff report.

Jinkook, L., \& Horacio, S. B. (1997). Consumer Vulnerability to Fraud: influencing factors. Journal of Consumer Affairs, 31(1), 70-89. http://dx.doi.org/10.1111/j.1745-6606.1997.tb00827.x

KAM (2012). The study to determine the severity of the counterfeit problem in Kenya. Nairobi: Kenya Association of Manufacturers.

Kenya National Bureau of Statistics (Various). Statistical Abstract. Nairobi: Government printer.

KIPPRA, \& UNODC. (2010). Victimization Survey in Kenya. Nairobi: Kenya Institute for Public Policy Research and Analysis.

KPMG (2003). Fraud Survey (Forensic). KPMG.

Kusic, J. (1989). White Collar Crime Prevention Handbook. Vienna, VA: White Collar Crime.

Macdonald, Z. (1998). The under-reporting of property crime: A micro econometric analysis. In Discussion paper in Public Sector Economics. Department of Economics, University of Leicester.

McGhee, J. L. (1983). Vulnerability of elderly consumers. International Journal of Aging and Human Development, 17(3), 223-246. http://dx.doi.org/10.2190/7J2P-DGE5-GYHH-DCRX

Moore, E., \& Mills, M. (1990). The Neglected Victims and Unexamined Costs of White Collar Crime. Crime and Deliquency, 36, 408-418. http://dx.doi.org/10.1177/0011128790036003007

Mustaine, E. E., \& Tewksbury, R. A. (2000). Comparing the Lifestyles of Victims, Offenders, and Victim-Offenders: A Routine Activity Theory Assessment of Similarities and Differences for Criminal Incident Offenders. Sociological Focus, 33(3), 339-362.

PWC (2014). Economic Crime: a threat to business processes (Global Economic Crime Survey: Kenya Report). Price Waterhouse Coopers.

Pyramid Schemes Commission (2010). Nyenze Taskforce report on pyramid schemes. Nairobi, Kenya. 
Skogan, W. G. (1984). Reporting crime to the police: The status of World research. Journal of Research in Crime and Delinquency, 21, 113-137. http://dx.doi.org/10.1177/0022427884021002003

Titus, R. M., Heinzelmann, F., \& Boyle, J. M. (1995). Victimization of Persons by Fraud. Crime and Delinquency, 41(1), 54-72. http://dx.doi.org/10.1177/0011128795041001004

Tseloni, A. (2000). Personal Criminal Victimization in the US: Fixed and Random Effects of Individual and Household Characteristics. Journal of Quantitative Criminology, 16(4), 415-442. http://dx.doi.org/10.1023/A:1007547115344

UNICRI (2000). International Criminal Victimization Survey. United Nations Interregional Crime and Justice Research Institute. Retrieved from http://www.unicri.it/services/library_documentation/publications/icvs/data/

UNODC (2005). Report on why fighting crime can assist development in Africa. United Nations Office on Drugs and Crime.

Zhang, L., Messner, S. F., \& Liu, J. (2007). An exploration of the determinants of reporting crime to the police in the city of Tianjin, China. Criminology, 45(4), 959-983. http://dx.doi.org/10.1111/j.1745-9125.2007.00093.x

\section{Appendix}

Appendix 1: Descriptive statistics ( $\mathrm{N}=644)$

\begin{tabular}{|c|c|c|c|c|}
\hline Variable & Proportion & Std. Error. & $95 \%$ Conf. & Interval \\
\hline \multicolumn{5}{|l|}{ GEN } \\
\hline Female & 0.5729814 & 0.0195069 & 0.5343136 & 0.6107773 \\
\hline Male & 0.4270186 & 0.0195069 & 0.3892227 & 0.4656864 \\
\hline \multicolumn{5}{|l|}{ LOC } \\
\hline Urban & 0.5108696 & 0.0197134 & 0.4721713 & 0.549438 \\
\hline Rural & 0.4891304 & 0.0197134 & 0.450562 & 0.5278287 \\
\hline \multicolumn{5}{|l|}{ EDUC } \\
\hline $\begin{array}{l}\text { No education/incomplete } \\
\text { primary }\end{array}$ & 0.2950311 & 0.0179851 & 0.2609812 & 0.3315304 \\
\hline Primary & 0.2437888 & 0.0169326 & 0.2120897 & 0.2785508 \\
\hline Secondary & 0.3167702 & 0.0183464 & 0.2818886 & 0.3538413 \\
\hline University/college & 0.1444099 & 0.013862 & 0.1192614 & 0.1738149 \\
\hline \multicolumn{5}{|l|}{ TYP } \\
\hline $\begin{array}{l}\text { Paid for nonexistent } \\
\text { services/goods or stolen } \\
\text { forged/forged cheque }\end{array}$ & 0.1490683 & 0.0140454 & 0.1235366 & 0.1788004 \\
\hline $\begin{array}{l}\text { Given fake goods/poor } \\
\text { services }\end{array}$ & 0.6521739 & 0.0187827 & 0.6144406 & 0.688089 \\
\hline $\begin{array}{l}\text { Fraudulent schemes and } \\
\text { others }\end{array}$ & 0.1987578 & 0.0157376 & 0.1696474 & 0.2314708 \\
\hline
\end{tabular}




\section{1) Macrothink}

Research in Applied Economics

ISSN 1948-5433

2014, Vol. 6, No. 3

\begin{tabular}{|c|c|c|c|c|}
\hline VAL & & & & \\
\hline $0-1000$ & 0.6925466 & 0.0181974 & 0.6557092 & 0.727083 \\
\hline $1001-10000$ & 0.2639752 & 0.0173829 & 0.2312808 & 0.2994906 \\
\hline $10001-100000$ & 0.0341615 & 0.0071633 & 0.0225718 & 0.0513891 \\
\hline $100001-1500000$ & 0.0093168 & 0.0037887 & 0.0041826 & 0.0206226 \\
\hline \multicolumn{5}{|l|}{ PER } \\
\hline Very good job & 0.136646 & 0.0135453 & 0.1121575 & 0.1654847 \\
\hline Fairly good job & 0.4192547 & 0.0194593 & 0.3815977 & 0.4578762 \\
\hline Fairly poor job & 0.2484472 & 0.0170409 & 0.21651 & 0.2833915 \\
\hline Very poor job & 0.1956522 & 0.0156444 & 0.1667413 & 0.228203 \\
\hline \multicolumn{5}{|l|}{ INC } \\
\hline $0-<50000$ & 0.9440994 & 0.0090597 & 0.9234072 & 0.9594469 \\
\hline $50000-<100000$ & 0.0248447 & 0.0061383 & 0.0152551 & 0.0402163 \\
\hline$>=100000$ & 0.0310559 & 0.0068409 & 0.020098 & 0.0476976 \\
\hline \multicolumn{5}{|l|}{ MAR } \\
\hline Single & 0.2329193 & 0.0166693 & 0.2017963 & 0.2672353 \\
\hline $\begin{array}{l}\text { Married/living as a } \\
\text { couple }\end{array}$ & 0.6723602 & 0.0185095 & 0.6350372 & 0.7076238 \\
\hline $\begin{array}{l}\text { Divorced/separated or } \\
\text { widow/widowed }\end{array}$ & 0.0947205 & 0.011548 & 0.0743463 & 0.1199545 \\
\hline \multicolumn{5}{|l|}{ NOH } \\
\hline 1 to 3 (small) & 0.3291925 & 0.0185318 & 0.2938763 & 0.3665498 \\
\hline 4 to 6 (medium) & 0.4968944 & 0.0197177 & 0.4582713 & 0.5355546 \\
\hline 7 to 10 (large) & 0.173913 & 0.0149477 & 0.1464836 & 0.2052436 \\
\hline \multicolumn{5}{|l|}{ OCC } \\
\hline Working & 0.4378882 & 0.0195653 & 0.3999137 & 0.4766047 \\
\hline $\begin{array}{l}\text { Looking for } \text { work } \\
\text { (unemployed) }\end{array}$ & 0.1086957 & 0.0122748 & 0.0868332 & 0.1352472 \\
\hline $\begin{array}{l}\text { Keeping home or retired, } \\
\text { disabled }\end{array}$ & 0.234472 & 0.0167079 & 0.2032649 & 0.2688536 \\
\hline $\begin{array}{l}\text { going to school / college } \\
\text { or other }\end{array}$ & 0.2189441 & 0.0163081 & 0.188606 & 0.2526428 \\
\hline \multicolumn{5}{|l|}{ AGG } \\
\hline$<25 \mathrm{yrs}$ & 0.2375776 & 0.016784 & 0.2062041 & 0.2720884 \\
\hline $26-35 y r s$ & 0.3291925 & 0.0185318 & 0.2938763 & 0.3665498 \\
\hline $36-55 y r s$ & 0.318323 & 0.0183704 & 0.2833854 & 0.3554315 \\
\hline$>55 \mathrm{yrs}$ & 0.1149068 & 0.0125766 & 0.0924235 & 0.1420038 \\
\hline
\end{tabular}




\section{Notes}

Note 1. To lay a formal complaint to the authorities with an intent to; recover lost property, punish the offender, and prevent future occurrence of the same

Note 2. Keynote address by Honorable Amos Wako, former Attorney General of Kenya, during the Third Global Conference on Combating Counterfeiting \& Piracy at the International Conference Centre in Geneva, Switzerland on January 30, 2007. Available at http://www.ccapcongress.net/archives/Geneva/Files/Wako.pdf

Note 3. It's a form of consumer fraud

Note 4. The variance inflation factor measures the impact of collinearity among independent variables in a regression model on the precision of estimation. It shows how the variance of an estimator is inflated by the presence of muliticollinearity. A variance inflation factor will be 1 if there is no collinearity between any two independent variables, while it will increase as the extent of collinearity increases with a value of 10 being considered high. a tolerance value of less than 0.1 is comparable to a VIF of 10 .

Note 5 . Since $p=0.0096$ and $<$ than 0.05 , the null hypothesis of homoskedasticity is rejected.

\section{Copyright Disclaimer}

Copyright reserved by the author(s).

This article is an open-access article distributed under the terms and conditions of the CreativeCommons Attribution license (http://creativecommons.org/licenses/by/3.0/). 